\title{
Designing Mechanisms to Govern Takeover Defenses: Private Contracting, Legal Intervention, and Unforeseen Contingencies
}

\author{
Jennifer Arlen†
}

During the takeover wave of the 1980s, managers developed numerous strategies to fend off unwanted bidders and retain control of their firms. These strategies included the poison pill, often used in combination with the effective classified board. Corporate scholars expressed concern over the serious conflict of interest inherent in managerial control over takeovers, arising from the fact that takeovers often presage managerial termination. Many corporate scholars argued that the poison pill should be prohibited. ${ }^{1}$ Many also concluded that managers should be required to submit bids to shareholders. ${ }^{2}$

Responding to the fundamental conflict attending board-enacted takeover defenses, the Delaware Supreme Court initially provided for heightened scrutiny of takeover defenses adopted by the board. ${ }^{3}$ In Unocal v Mesa Petroleum ${ }^{4}$ the Delaware Supreme Court announced a twotiered proportionality review of takeover defenses. The first prong entails an assessment of whether the board was responding to a legitimate threat to corporate policy and effectiveness. ${ }^{5}$ The second prong asks the

$\dagger$ Visiting Professor, Yale Law School; Ivadelle and Theodore Johnson Professor of Law and Business, University of Southern California Law School. I would like to thank Bentley MacLeod, Ehud Kamar, Alan Schwartz, and Eric Talley for helpful comments.

1 See Marcel Kahan and Edward B. Rock, How I Stopped Worrying and Learned to Love the Pill: Adaptive Responses to Takeover Law, 69 U Chi L Rev 871,876 n 16 (2002) (discussing opposition to the poison pill).

2 See, for example, Lucian A. Bebchuk, Comment, The Case for Facilitating Competing Tender Offers, 95 Harv L Rev 1028,1034-38 (1982) (arguing for an auctioneering rule that requires managers to solicit competing bids and then submit them to shareholders); Ronald J. Gilson, $A$ Structural Approach to Corporations: The Case Against Defensive Tactics in Tender Offers, 33 Stan L Rev 819, 844-48(1981) (stating that shareholders' unrestricted access to tender offerors is necessary to impose constraints on managers).

3 Unocal Corp y Mesa Petroleum Co,493 A2d 946,954 (Del 1985) ("Because of the omnipresent specter that a board [when addressing a pending takeover bid] may be acting primarily in its own interests, rather than those of the corporation and its shareholders, there is an enhanced duty which calls for judicial examination at the threshold before the protections of the business judgment rule may be conferred.").

4493 A2d 946 (Del 1985).

5 Id at 955 ("[D]irectors must show that they had reasonable grounds for believing that a danger to corporate policy and effectiveness existed because of another person's stock ownership."). 
court to determine whether the defensive measure was proportionate to the threat posed. ${ }^{6}$

The Unocal standard initially appeared to offer the promise of court review of both the purposes for and structure of takeover defenses. ${ }^{7}$ It thus appeared to place some effective limitations on the board. This promise largely evaporated with the Delaware Supreme Court's decisions in Unitrin, Inc v American General Corp ${ }^{8}$ and Paramount Communications, Inc v Time-Warner, Inc. In these decisions, the Delaware Court effectively removed the teeth from both prongs of the Unocal standard. The court concluded that the board could defend against a noncoercive all-cash, all-shares offer if it determined that the price was too low. Moreover, the court permitted the board to employ any defensive measure it preferred provided the measure was not "preclusive or coercive."10 Finally, the court also concluded that the board could "just say no" to an acquisition."

Many commentators decried this development in Delaware law. They argued that "just say no" would reduce shareholder welfare by giving the board control over takeovers, a central mechanism for disciplining the board. Leading corporate scholars asserted that shareholder welfare would be maximized by giving shareholders ultimate control over tender offer defenses, thereby wresting from the board managerial authority over this area."

6 Id ("If a defensive measure is to come within the ambit of the business judgment rule it must be reasonable in relation to the threat posed.").

7 The potential for court supervision of takeover defenses was undercut by the Delaware Court's decision to grant business judgment rule-like review to the board's assessment of the threat posed. Id at 954 . As a result, the court would credit an informed board's statement that a takeover bid was too low, and a responsive measure (such as a self-tender) was at a fair price, even if this claim by the board did not entirely seem credible. See id at 958-59 (concluding that a discriminatory "scorched earth" self-tender was a proportionate response because the informed board concluded that the self-tender at a substantial premium offered a fair price for the shares).

$8 \quad 651$ A2d 1361 (Del 1995).

9571 A2d 1140 (Del 1989).

10 See Unitrin, 651 A2d at 1388 (noting that "if the board of directors' defensive response is not draconian (preclusive or coercive) and is within a 'range of reasonableness,' a court must not substitute its judgment for the board's").

11 Time-Warner,571 A2d at 1154-55 (holding that "[d]irectors are not obliged to abandon a deliberately conceived corporate plan for a short-term shareholder profit unless there is clearly no basis to sustain the corporate strategy").

12 See, for example, Bebchuk, Comment,95 Harv L Rev at 1054 (cited in note 2) (arguing that managers cannot be trusted with the power to use obstructionist tactics to block bids); Frank $\mathrm{H}$. Easterbrook and Daniel R. Fischel, The Proper Role of Target's Management in Responding to a Tender Offer, 94 Harv L Rev 1161, 1194-1204 (1981) (claiming that rules allowing management to engage in defensive tactics in response to a tender offer decrease shareholders' welfare); Gilson, 33 Stan L Rev at 865 (cited in note 2). While most agree that shareholders should be given the choice, they differ on whether shareholders should evaluate bids individually or collectively, by requiring a majority vote on any tender offer. Compare Lucian Arye Bebchuk, Toward Undistorted Choice and Equal Treatment in Corporate Takeovers, 98 Harv L Rev 1693,1702-06 (1985) (shareholder vote is preferable), and Lucian Bebchuk and Oliver Hart, Takeover Bids vs. Proxy Fights in Contests for 
In their contribution to this Symposium, Marcel Kahan and Ed Rock argue that critics of Delaware law may have overstated both the adverse effects of the change in Delaware law and the need for reform. Many proposals for legal intervention presume an essential role for law, largely because they implicitly assume that corporate constituentsshareholders and managers-do not themselves act to redress the problem of board agency costs in adopting takeover defenses. By contrast, Kahan and Rock claim, corporate constituents can, and do, act to reduce agency costs by employing "adaptive devices." This widespread use of private solutions to board agency costs suggests that the development of the poison pill and adoption of "just say no" have not necessarily had a decisive negative impact on corporate welfare, Kahan and Rock assert. ${ }^{13}$ This warrants reexamination of the conventional wisdom regarding the need to change Delaware law governing takeovers, they conclude.

Kahan and Rock's recognition of the availability of private solutions to the problem of the board's conflict of interest in responding to tender offers is important, especially since private parties have a range of instruments available to them that are not available to the courts. ${ }^{14}$ Nevertheless the possibility of private action does not necessarily lead to the conclusions they reach regarding the significance-or relative lack thereof-of Delaware law governing takeovers. Notwithstanding the possibility of private action, Delaware law may play a vital role because private parties cannot necessarily remedy all agency cost problems associated with tender offers, and courts have instruments available to them that are not available to the parties. Appropriate legal intervention thus may extend beyond adopting optimal default rules parties might adopt to include interventions designed to redress problems the parties cannot solve themselves. Thus optimal legal regimes may operate in concert with private "contracting" by altering the set of feasible private solutions. A suboptimal legal regime can result in suboptimal private agreements. Thus, legal intervention may matter a great deal even when parties can adopt mechanisms to govern a particular issue. An optimal legal regime can enable the parties to adopt arrangements that they otherwise could not (or would not), increasing the parties' joint welfare.

Corporate Control at 22-34, Harvard John M. Olin Discussion Paper No 336 (Oct 2001), available online at <http://www.law.harvard.edu/programs/olin_center/> (visited Feb 19, 2002) (same), with Ronald J. Gilson and Alan Schwartz, Sales and Elections as Methods for Transferring Corporate Control, 2 Theor Inq in L 783,790-92 (2001) (straight tender offer is preferable to requiring shareholder voting on tender offers).

13 Kahan and Rock, $69 \mathrm{U}$ Chi L Rev at 911 (cited in note 1) (concluding that "the pill contributed to a new equilibrium in which it seems to have been transformed into a device that plausibly is in shareholders' interests").

14 Id at 900-01 (arguing that the takeover experience demonstrates how the possibility of private strategic action makes it very difficult to predict the effects of legal development).

15 I am using the term "contracts" to refer to arrangements included in the voluntary agree- 
Legal intervention may be particularly important with respect to tender offer defenses because private contracting in this area is adversely affected by many problems, some of which may best be addressed by legal intervention. One important problem, considered here, is that of unforeseen contingencies. This limitation is aggravated by the problem of unverifiability. Corporate constituents' ability to employ private solutions to address the takeover defense problem is limited by the fact that they cannot easily contract to prohibit, or limit the scope of, antitakeover devices. Corporate constituents cannot write contracts that prohibit "antitakeover devices," for example, because it often is difficult to define the term: it is often hard to determine whether a corporate action is an antitakeover device or a legitimate business action. This is particularly true of antitakeover devices employed in advance of a tender offer. Nor can corporate constituents circumvent this problem by identifying and individually prohibiting each potential antitakeover device because they cannot fully anticipate all the measures a board might employ. These other measures might be worse for the firm than the prohibited measures. Thus, absent legal intervention, shareholders who otherwise might wish to limit defensive measures may nevertheless prefer not to restrict the board's power to employ well-known measures, such as the poison pill, for fear that the board will instead use even more destructive devices. By contrast, under a legal regime entailing more careful court scrutiny of board responses to the takeover threat, shareholders might seek to restrict takeover defenses. This regime might thus be welfareimproving.

Accordingly, the conclusion that private parties can respond to the Delaware Court's adoption of "just say no" does not imply that "just say no" did not significantly reduce shareholder welfare. The doctrine leaves shareholders vulnerable to unpredictable strategic board action, in ways the parties cannot adequately redress through private arrangements. Even with private solutions it remains to be considered whether Delaware courts potentially could improve shareholder welfare by altering Delaware antitakeover law to limit the scope of antitakeover defenses. Thus, while private agreements must be taken into account, they do not necessarily replace the need for legal intervention in this area.

\section{TAKEOVER DEFENSES AND AGENCY COSTS}

To understand the strength of Kahan and Rock's views concerning private solutions to takeover defenses, it is important to recognize that shareholders could benefit from board control over takeovers if share-

ments that govern intrafirm relationships between shareholders and managers, whether or not these are true legal contracts resulting from bilateral agreements. In other words, the term is used to encompass what Rock and Kahan refer to as "adaptive devices." 
holders could eliminate (or reduce) the problem of board agency costs. Indeed, board control over takeover defenses might be optimal in a world in which "complete contracting" between shareholders and managers is possible.

Takeover defenses can benefit shareholders in a variety of ways, were boards loyal agents of shareholders. For example, takeover defenses benefit shareholders by enabling them to resist structurally coercive offers, such as the front-loaded two-tiered tender offer involved in Unocal. ${ }^{16}$ In addition, takeover defenses may benefit shareholders faced with a tender offer at an excessively low price. Shareholders face collective action problems when deciding how to respond to a takeover bid. Unable to negotiate a higher price, shareholders may find it in their individual interests to accept a low-price offer that it would be in their collective interests to reject. Board control over takeover defenses potentially can enable shareholders to redress this problem by enabling the board, in effect, to bargain collectively on behalf of shareholders."

Board control also could benefit shareholders because the board is likely to be better informed about the relative merits of an acquirer's offer. The value of an offer to shareholders is not simply the price offered, but rather is the expected value of the deal. This depends on both the value of the consideration offered and the expected value of the target should the deal fail subsequent to the offer being accepted. ${ }^{18}$ The possibility of noncompletion must be taken into account since a significant percentage of signed deals do indeed fail to go through and nonconsummation can depress the target's price below its pre-bid level. ${ }^{19}$ Failure of an accepted deal can reduce the target's value below its prebid level in part because the target may undergo changes after the deal is

16493 A2d 946 (Del 1985).

17 For a more detailed discussion of the collective action problem see Lucian Bebchuk, The Case Against Board Veto in Corporate Takeovers, 69 U Chi L Rev 973,981 (2002) (noting that the collective action problem here is a familiar one and "most visible and conspicuous in the case of partial, two-tier bids"); Bebchuk and Hart, Takeover Bids vs. Proxy Fights in Contests for Corporate Control at 3 (cited in note 12) (analyzing the collective action problems associated with different mechanisms for changing corporate control); Bebchuk, 98 Harv L Rev at 1719-35 (cited in note 12) (examining the causes of and difficulties posed by distortion of shareholders' tender decisions).

18 As Ehud Kamar has noted, the expected value of an offer is a function of both the consideration offered and the probability that a signed deal will go through. See Ehud Kamar, Managerial Change-in-Control Benefits and Takeovers at 4, working paper (Jan 2002) (on file with author). The expected gain to target shareholders from an acquisition, therefore, is given by:

\{(prob deal completed) (bid price) + (prob deal not completed) (value target if deal fails)\} pre-bid price of target

19 Even friendly deals face a significant risk of noncompletion. A study of negotiated mergers between 1988-1999 found that 24 percent of these deals were not completed if there was no lock-up or break-up fee and 5 percent were not completed even with both a lock-up and break-up fee. See John C. Coates IV and Guhan Subramanian, A Buy-Side Model of M\&A Lockups:Theory and Evidence, 53 Stan L Rev 307, 347 (2000). 
announced but before the deal is completed-including the loss of key personnel. Managers are likely to have better information than shareholders on both the probability and the potential cost of deal failure, giving them superior information on an important component of bid value. This potentially gives the board an informational advantage in assessing a bid even when the offer is all cash, the firm is actively followed by analysts, and institutional shareholders have significant holdings.

Although shareholders could benefit from leaving loyal managers in charge of takeovers, in practice strong reasons exist for being concerned about granting boards the power both to fend off tender offers and to shape those deals that are accepted. Managers are concerned with their own welfare, in particular the potential loss of their jobs following an acquisition, and thus may attempt to defeat any bid not in their own personal interests. Indeed, managers are particularly likely to attempt to defeat a takeover when an acquisition is most beneficial to shareholders: when the firm is underperforming as a result of poor management. Finally, managers may use takeover defenses to alter the structure of payments made in an acquisition -increasing the benefit to managers of the acquisition at the expense of shareholders. ${ }^{20}$

Most law-and-economics scholars weighing the advantages of board control over defensive measures against the costs have concluded that board control over defensive measures is inefficient. Most law-andeconomics corporate scholars support proposals that restrict the board's ability to veto takeovers in favor of leaving the matter up to shareholders." These scholars thus have decried the Delaware Supreme Court's decision effectively to eviscerate Unocal's proportionality review and to permit boards to "just say no" to hostile tender offers without submitting bids to shareholders.

\section{KAHAN AND ROCK ON MECHANISM DESIGN}

A central limitation of existing analysis, Marcel Kahan and Ed Rock argue, is that it implicitly assumes that the problem of board agency costs when responding to takeovers requires legal intervention. This is not necessarily the case, they observe. The parties themselves-shareholders and

20 Managerial side payments can take a variety of forms, from lucrative post-deal consulting contracts to significant additional golden parachutes or executive stock options. See Kamar, Managerial Change-in-Control Benefits and Takeovers at 4-6 (cited in note 18) (exploring the increase in managers' conflicts of interest in evaluating acquisitions potentially created by executive stock options).

21 See, for example, Bebchuk, Comment, 95 Harv L Rev at 1054 (cited in note 2) (arguing for an auctioneering rule that requires managers to solicit competing bids and then submit them to shareholders ); Easterbrook and Fischel, 94 Harv L Rev at 1194-1204 (cited in note 12) (arguing that management should be passive in the face of tender offers); Gilson, 33 Stan L Rev at 876 (cited in note 2) (stating that "[s]hareholders must make tender offer decisions"). 
and managers - also can implement mechanisms to govern takeover defenses. Accordingly, Kahan and Rock argue, scholars considering legal intervention to govern defensive measures must first take into account the possibility of private action. ${ }^{2}$ To the degree to which the parties can ameliorate the problem of board agency costs on their own, additional legal intervention may not be necessary.

Kahan and Rock's central insight about the existence of private solutions to the board's agency cost problems is an important contribution to the literature on tender offer defenses. Existing analyses generally assume that "shareholder choice" default rules are needed because contracting costs impair the ability managers and shareholders to adopt optimal arrangements to govern tender offers. Yet, Kahan and Rock observe, private parties not only can, but do, adopt a variety of mechanisms for dealing with the board's agency costs. ${ }^{23}$ These existing private solutions must be considered even though shareholders and managers generally do not bargain over terms of the corporate contract in the traditional sense. $^{24}$

Attention to private arrangements is particularly important because shareholders and managers have a different range of solutions available to them than do the courts. ${ }^{25}$ For example, the parties can affect the structure of managerial compensation packages, whereas the courts cannot. This wider range of mechanisms presents the possibility that corporate constituents can structure the board's incentives to limit the adverse consequences of the board's conflict of interest while retaining the benefits of the board's informational advantage regarding takeovers. Thus, Kahan and Rock's analysis requires that those seeking legal intervention defend

22 Kahan and Rock, 69 U Chi L Rev at 900-01 (cited in note 1).

23 Id at 883-87.

24 The fact that these solutions are not adopted as part of a classic "contract" negotiation does not undermine Kahan and Rock's claim that these provisions can be thought of as being contractual, in the sense of being provisions both shareholders and managers prefer and, in effect, agree to. Boards may respond to market forces that cause them to internalize shareholders' preferences in designing corporate charter and bylaw provisions. This could lead corporate arrangements to mimic the results of bilateral bargaining between managers and shareholders. For example, managers might be induced to implement optimal terms prior to an initial public offering because they tend to be the residual claimants of an IPO and thus benefit from terms that shareholders value. This depends on IPOs being priced efficiently, however. In addition, managers might subsequently be induced to adopt charter provisions preferred by shareholders if: (i) institutional share ownership is sufficiently great that managers fear a proxy contest; or (ii) if the company needs to return regularly to the equity markets for additional capital in circumstances where managers benefit from obtaining the lowest cost of capital possible. Indeed, the cornerstone of corporate law scholarship - the nexus of contracts-presumes that corporate law should focus on enabling statutes because parties can contract around suboptimal provisions. It is rarely assumed that this would be contracting in the classic sense, but rather that managers would respond to market forces in selecting charter and bylaw provisions.

25 Kahan and Rock, $69 \mathrm{U}$ Chi L Rev at 888-89 (cited in note 1) (noting that private responses offer greater flexibility and an opportunity for fine tuning). 
not only the merits of their proposals, but also explain why any proposed legal intervention should supplant private efforts to solve the problem. Corporate constituents' access to a rich array of private solutions to the tender offer problem leads Kahan and Rock to conclude that Delaware takeover defense law plays a less significant role than is generally believed. Thus, scholars need not be particularly concerned about either the Delaware Supreme Court's "just say no" doctrine or its effective elimination of any serious proportionality review. ${ }^{26}$ Moreover, Kahan and Rock cast doubt on whether "shareholder choice" is indeed the optimal default rule by observing that existing "adaptive devices" generally do not give shareholders power over tender offers. Kahan and Rock observe that corporations generally have eschewed "shareholder choice" without widespread objection from shareholders. For example, none of the three hundred companies that went public between 1994 and 1997 limited the board's ability to implement a poison pill or mandated shareholder choice on takeovers. In fact, a majority of firms conducting initial public offerings increased managers' power to fend off tender offers by classifying the board and limiting shareholders' ability either to get a special meeting or act through written consent. Similarly, in the case of existing firms, institutional shareholders have not tried to prohibit poison pills, nor have they rallied behind the shareholder choice proposals that many scholars claim are in their interests. ${ }^{2 k}$ This evidence of apparent shareholder acceptance of board power over defensive measures potentially casts doubt on assertions that "shareholder choice" maximizes shareholder welfare. ${ }^{29}$

26 Id at $900-01$.

27 Id at 885 .

28 Id at $885-87$.

29 The possibility that such rules are suboptimal is a potential concern for their proponents even though these rules are proposed simply as default rules because suboptimal court-adopted default rules can reduce the parties' joint welfare. Adoption of a suboptimal but welfare-improving default rule can make the parties worse off than otherwise because introduction of the rule may result in the parties failing to adopt optimal provisions they otherwise would have adopted. This may occur where, absent legal intervention, the gain to the parties of redressing the problem exceeded the contracting costs, but with the suboptimal default rule any remaining problems are no longer large enough to warrant the expenditure needed to eliminate it entirely. For a discussion of the problems of designing optimal default rules see, for example, Ian Ayres and Robert Gertner, Majoritarian vs. Minoritarian Defaults, 51 Stan L Rev 1591,1611 (1999) (identifying principles that should guide "efficiency-minded lawmakers" in creating default rules); Ian Ayres and Robert Gertner, Strategic Contractual Inefficiency and the Optimal Choice of Legal Rules, 101 Yale L J 729,762 (1992) (arguing that when contracting around default rules is costly "the appropriate choice of default can depend on a variety of underlying variables that are independent of the hypothetical contract that parties would sign in a world without transaction costs"); Ian Ayres and Robert Gertner, Filling Gaps in Incomplete Contracts: An Economic Theory of Default Rules, 99 Yale L J 87, 127-28 (1989) (arguing for penalty defaults when strategic bargaining may impede parties from bargaining around default rules). See also Barry E. Adler, The Questionable Ascent of Hadley v. Baxendale, 51 Stan L Rev 1547, 1581 (1999) (concluding that "it may be harder than once believed to determine" whether conditions exist such that a penalty default rule is appropriate). Additionally, courts and legislatures must take care to 
In contrast with shareholder choice proposals, existing private arrangements leave the board in control of tender offers and employ various mechanisms designed to reduce the board's agency costs when defending against takeovers. A growing number of firms require a majority of outsiders on the board. In addition, many firms now employ executive stock options with early vesting on "change of control" to provide managers with an incentive to support a takeover and negotiate for a higher price. ${ }^{30}$ Indeed, executive stock options with "change of control" vesting provisions not only lower board resistance to tender offers, but may encourage boards to support tender offers. ${ }^{31}$

Kahan and Rock's analysis thus suggests that the prevalence of "adaptive devices" indicates that corporate constituents are capable of redressing problems associated with the board's conflict of interest in responding to tender offers. This suggests it may not be necessary to reform existing Delaware law. Moreover, even if reform were warranted, their analysis of the regimes actually adopted by corporate constituents implies that it would not necessarily be optimal to adopt any of the proposed "shareholder choice" regimes.

\section{ROLE OF LAW IN REDRESSING INCOMPLETE CONTRACTS}

Kahan and Rock's insight that corporate constituents can-and do-act to redress agency cost problems and have a greater variety of mechanisms available to them than do the courts is an important contribution to the literature. This alters the nature of arguments for legal intervention to considerations of the relative merits of legal versus private action. Nevertheless, Kahan and Rock's analysis does not necessarily support the ultimate policy conclusions they reach. In particular, the availability of private arrangements does not necessarily reduce the importance of legal intervention or imply that the development of "just say no" was any less damaging than previously believed. Nor does the cur-

avoid enacting suboptimal default rules if lawyers and corporate constituents exhibit status quo bias and thus do not contract around default rules even when it would be in their best interests to do so. See, for example, Russell Korobkin, The Status Quo Bias and Contract Default Rules, 83 Cornell L Rev 608, 675 (1998) (arguing that parties might "fail to contract around inefficient defaults when their preference for maintaining the status quo relative to alternative states swamps their preference for the alternative contract term relative to the default term").

30 Executive stock options with long vesting periods and "change of control provisions" provide managers with an incentive to both favor tender offers and to negotiate a higher price,notwithstanding potential future job loss. Thus, such provisions potentially reduce the board's conflict of interests in responding to tender offers while enabling the shareholders to potentially benefit from the board's informational advantage in assessing tender offers. Id at 15-17,40. For a discussion of the incentives these options can provide to the board see Kamar, Managerial Change-in-Control Benefits and Takeovers at 4-6 (cited in note 18) (emphasizing the importance of early vesting provisions).

31 For an excellent discussion of the impact of executive stock options on a board's incentives to accept a tender offer bid, see Kamar, Managerial Change-in-Control Benefits and Takeovers (cited in note 18). 
rent pattern of corporate agreements necessarily suggest that "shareholder choice" is a suboptimal rule.

The fact that parties voluntarily adopt mechanisms to address takeover-defense agency costs does not necessarily suggest that there is little role for law. Indeed, the economics literature on incomplete contracts reveals that legal intervention may be a requisite for optimal contracting because, absent optimal legal intervention, contracting parties may voluntarily adopt suboptimal agreements. Courts and parties may both have a role to play in reducing problems associated with incomplete contracts because each may be able to respond to agency cost problems in different ways. Just as parties can employ mechanisms not available to courts, courts can use mechanisms not available to the parties. Thus legal intervention is not necessarily a substitute for private contracting, but rather may increase the parties' ability to write optimal private agreements. Moreover, the agreements parties reach in the presence of optimal legal intervention may differ significantly from those they would adopt in the absence of such intervention. Existing arrangements may be an appropriate response to the prevailing legal regime, but they may not be optimal if the legal regime itself is suboptimal.

This Part examines the potential role for law in limiting a particular problem associated with designing "adaptive devices" to address tender offer defenses - that of unforeseen contingencies associated with takeover defenses. It shows that Delaware's adoption of "just say no" may have affected the nature of the adaptive devices available to corporate constituents. This could have reduced shareholder welfare notwithstanding widespread use of bilateral adaptive devices.

\section{A. Incomplete Contracts and Unforeseen Contingencies}

Corporate law scholarship has focused primarily on one of the many types of impediments to contracting: "contracting costs." Concern for contracting costs as the central impediment to private agreements leads to two conclusions: (1) legal rules should focus on solving the substantive problems facing parties by providing optimal default rules; and (2) legal rules need not intervene when parties appear to be redressing agency cost problems themselves. This standard view of contractual incompleteness naturally leads to Kahan and Rock's conclusion that court intervention is not needed if parties are solving problems themselves through private bilateral agreements.

Yet "costly contracting" is not the only barrier to optimal corporate contracting; other contracting problems exist. ${ }^{32}$ Of particular importance

32 Although the present analysis focuses on unforeseen contingencies, other problems exist that may warrant legal intervention. See, for example, W. Bentley MacLeod, Complexity and Contract, working paper (Apr 2001), available online at <http://hal-law.usc.edu/cleo/conferences/ 
in the tender offer context, private action is plagued by problems arising from unforeseen contingencies. ${ }^{33}$ Boundedly rational parties cannot predict, and thus cannot contract over, all future possibilities. This impedes optimal contracting. One obvious effect of unforeseen contingencies is that the parties' contract will be incomplete: it will not specify the desired payoffs should the unforeseen event occur. This possibility forms the cornerstone of much of the contracts literature on optimal default rules. $^{34}$

Evidence that a contingency (such as the poison pill) is foreseen and that corporate constituents are contracting-or adopting adaptive devices-might seem to suggest that unforeseen contingencies are not an issue. This is not the case. Unforeseen contingencies may cause parties to leave contracts vague or unspecified even with respect to contingencies they can predict.

Consider two parties writing a contract to govern a situation where each can take actions that affect the welfare of the other. Assume that the range of actions available to one party is foreseeable and easily subject to contracting, yet the range of options available to the other is not entirely foreseeable. Although the parties could write a contract specifying the obligations of the first party, they may fail to do so given their inability to fully constrain the actions available to the second party, or they may write a much less restrictive term than they otherwise would. Thus, in the presence of unforeseen contingencies available to the second party, the parties may leave the contract intentionally more vague than necessary in order to grant the first party the ability to respond to strategic behavior by the second.

be2001/macleod.pdf (visited Apr 19,2002); George J.Mailath and Andrew Postlewaite,Asymmetric Information Bargaining Problems with Many Agents, 57 Rev Econ Stud 351,352 (1990) (noting that it becomes difficult to fashion rules for cost-sharing when individual valuations are not known).

33 Nonverifiability is an additional problem. For example, shareholders cannot write a contract precluding "antitakeover devices" because it is difficult to verify that a particular corporate action is an antitakeover device. For example, a merger that increases a firm's debt/equity ratio considerably may be pursued for legitimate business reasons or may be motivated largely to deter tender offers.

34 See, for example, Oliver Hart and John Moore, Incomplete Contracts and Renegotiation, 56 Econometrica 755,757 (1988) (noting that boundedly rational parties "may be unable to anticipate every eventuality, and may find it too difficult to decide (and reach agreement about) how to deal with eventualities which they do foresee"). See also Herbert A. Simon, The Sciences of the Artificial 37-38 (MIT 2d ed 1981) (arguing that boundedly rational parties may not specify certain contingencies or recognize the need to specify some dimension of contractual performance). Unforeseen contingencies do not necessarily justify legal intervention. Under certain circumstances (not present here), parties may be able to redress the problem themselves. See Eric Maskin and Jean Tirole, $U n$ foreseen Contingencies and Incomplete Contracts, 66 Rev Econ Stud 83, 84 (1999) (arguing that if parties have trouble foreseeing the possible physical contingencies, they can write contracts that $e x$ ante specify only the possible payoff contingencies and that when the state of the world is realized, they can fill in the details).

35 See B. Douglas Bernheim and Michael D. Whinston, Incomplete Contracts and Strategic Ambiguity, 88 Am Econ Rev 902,903 (1998) (describing such incompleteness as "strategic ambiguity"). Professors Bernheim and Whinston give the following example of the use of strategic ambiguity to 


\section{B. Unforeseen Contingencies and Takeovers}

Contracting over tender offer defenses is plagued by considerations of unforeseen contingencies. For example, although shareholders and managers can foresee the possibility of a takeover and the possibility that the board will want to defend against it, they cannot predict the structure of all possible board defensive measures. Recognition of the importance of unforeseen contingencies affects both claims about the role of law when parties can adopt adaptive devices and the implications about optimal law that can be drawn from the structure of existing devices.

Given the great variety of defensive measures available to the board, shareholders may be reluctant to limit board power to adopt particular defensive measures - such as poison pills and classified boardsfor fear that boards would respond by adopting measures that are even more destructive. Accordingly, in the current legal climate the prevalence of classified boards does not necessarily imply that shareholders support effective classified boards-only that they prefer them to the range of "scorched earth" defenses that boards might employ otherwise.

Nor can shareholders necessarily eliminate the problem of boards' defensive measures through adoption of rules requiring shareholder choice in the event of a tender offer. Absent court oversight, boards would retain the power to frustrate shareholder choice rules through defensive measures undertaken ex ante, prior to announcement of a bid (such as restructuring the firm). ${ }^{36}$ Thus, shareholder choice may not be optimal in the current legal regime of relatively low court oversight of defensive measures.

Thus, the fact that in the current climate shareholders appear to accept board power to fend off takeovers-employing executive stock op-

respond to unforeseen contingencies. Consider the contracting problem between a faculty member and a university. This contract involves the possibility of strategic behavior on each side. The tenured faculty member may fail to be optimally productive. The university, in turn, can fail to provide the faculty member with the resources she needs to do her scholarship: for example, adequate future salary, resources for research, travel and conferences, adequate office space, secretarial support, and teaching schedule. The university's future obligations to the faculty member are relatively easy to identify ex ante, and can be readily specified in a contract. By contrast, the faculty member's obligations are more difficult to specify by contract (assuming the university cares about quality, as well as quantity, of scholarly output). The important insight of Bernheim and Whinston's analysis is that the parties' inability to contract over the professor's obligation to the university may lead them to also leave the university's obligations to the professor unspecified, even though delineating the latter would not be difficult. Leaving the university's obligations to the professor unspecified, by contrast, creates a relational contract which enables the university to provide the professor with incentives to give the desired level of performance. See id at 903-04.

36 See, for example, Hilton Hotels Corp v ITT Corp, 978 F Supp 1342, 1344 (D Nev 1997) (stating that a target board sought to institute a comprehensive plan whereby it would break itself into three separate corporations and prevent a bidder from acquiring the board positions on board of the largest of the three). 
tions geared to promote takeovers-does not imply such arrangements are optimal. Indeed, while existing executive stock options are a reasonable response to the current regime, reasons exist to suspect that this structure is not necessarily first-best optimal. As Professor Kamar has shown, executive stock options with "change of control" provisions may give boards excessive incentives to sell the company. ${ }^{37}$ Moreover, these provisions do nothing to ensure that shareholders receive the optimal amount of any gains resulting from an acquisition. Boards in control of acquisitions can reap a disproportionate share of the gains. ${ }^{38}$ Thus evidence that acquisitions continue in the wake of Delaware's "just say no" defense does not imply either that the acquisitions that occur are optimal or that acquisitions are structured optimally.

\section{Legal Intervention to Redress Unforeseen Contingencies}

Unforeseen contingencies may justify legal intervention even when private action is possible. Courts can reduce the distorting effects of unforeseen contingencies through the use of mechanisms not practicably available to the parties - such as legal standards. For example, a court can provide a form of insurance against unforeseen contingencies by precommitting to intervene on specified terms in the event of an unforeseen contingency. A central advantage of court action is that a court need not identify in advance the precise nature of the unforeseen contingency that will result in intervention. Rather, a court can employ a legal standard under which it commits to intervene should certain contingencies arise, with the nature of the intervention depending on the parties' ex post payoffs. Such a legal rule not only may reduce the cost of the occurrence of an unforeseen contingency itself, but also may increase the parties' joint welfare by reducing the risk to the parties of unforeseen contingencies. This can enable the parties to write better terms to govern those future actions they can foresee. Thus court intervention may be needed to enable the parties to write optimal agreements.

37 Kamar, Managerial Change-in-Control Benefits and Takeovers at 4-6,12-17 (cited in note 18) (noting that changes in control result in accelerated vesting of stock options and leads to greater incentives for sale).

38 See id at 6-23 (stating that the practice of sweetening existing executive compensation arrangements while deal negotiations are taking place is common).

39 See Luca Anderlini, Leonardo Felli and Andrew Postlewaite, Courts of Law and Unforeseen Contingencies at 5, Pennsylvania Institute of Economic Research Working Paper No 01-010 (March 2001), available online at $<\mathrm{http} / / \mathrm{www} . e c o n$.upenn.edu/Centers/pier/Archive/01-010.pds $>$ (visited Feb 19,2002 ) (creating a model of court intervention where the court determines whether to intervene by "trading off parties' incentive to invest with their desire for insurance in the event of unforeseen contingencies"). See also Maskin and Tirole, 66 Rev Econ Stud at 99-100 (cited in note 34) (noting that when courts have substantial discretionary authority, existence of unforeseen contingencies does not necessarily adversely affect payoff outcomes achievable through contracting). 
As applied to takeover defenses, this analysis presents the possibility that shareholders' and managers' joint welfare may well have been higher under Delaware's earlier takeover doctrine-which threatened to invalidate "disproportionate" takeover defenses - than it is presently under the current permissive approach towards boards' tender offer defenses. " "Just say no" removed the court from its previous role of limiting the range of strategic actions available to the board. If this legal change left shareholders more vulnerable to board defensive measures, then the change in law could well have both hurt shareholders and altered the acceptable range of adaptive devices. Thus the Delaware court's adoption of "just say no" may have had serious adverse consequences for shareholder welfare even though corporations adopted measures to reduce its adverse effect. Under a different regime with serious scrutiny of antitakeover measures, shareholders would likely adopt alternative adaptive devices. Indeed, should the Delaware Court ever adopt effective oversight of coercive bids and defensive measures (whether taken ex ante or ex post), shareholders might support "shareholder choice" rules.

\section{CONCLUSION}

Much of the literature on takeovers has focused on designing optimal default rules to govern takeover defenses. Such legal interventions typically are justified on the grounds that transactions costs may prohibit the parties from adopting optimal agreements themselves. This literature generally focuses on contracting costs as a primary source of contracting problems.

Kahan and Rock's Article makes a valuable contribution to this literature by revealing that private parties can, and do, devise solutions to address boards' agency costs in responding to tender offers. Indeed, parties have a greater range of options available to them than do the courts. Moreover, Kahan and Rock note that existing corporate agreements do not correspond to the strong "shareholder choice" rules proposed by corporate scholars.

40 Indeed, shareholder welfare might have been further improved had the Delaware court enhanced its Unocal standard by precluding boards from adopting excessive (in other words, valuereducing) tender offer defenses. Such a standard is reminiscent of the Delaware Court's original articulation of the Unocal standard, with one critical distinction: under this standard the court would determine itself whether the defensive measure is excessive, and would not simply accept an informed board's assertion that the measure is in the firm's best interests. Adoption of such a legal standard potentially could reduce the risk to shareholders of unforeseen board action, giving shareholders greater ability to regulate those measures they can foresee (such as classified boards). This is not to say that such a legal standard is necessarily optimal. Articulating an optimal legal rule to govern tender offer defenses is beyond the scope of this comment. The central purpose of considering such a rule is simply to illustrate that the interaction between the legal regime and the types of private agreements parties reach. 
This analysis is important for a number of reasons. First, it suggests that contracting costs cannot be assumed to preclude corporate constituents from designing solutions to the problem of tender offer defenses given evidence that such adaptive devices exist. Second, Kahan and Rock's analysis presents a challenge to scholars seeking to develop optimal mechanisms to regulate takeovers: revealing that such efforts must include consideration of the range of instruments available to the parties, in addition to those available to the courts. Finally, Kahan and Rock's evidence about the existing structure of corporate agreements raises the question of whether shareholder choice rules are optimal, given the lack of existing shareholder support for such proposals.

Nevertheless, the presence of private adaptive devices cannot be taken as evidence that the law governing takeovers is any less important than previously believed. Recognition of the courts' special ability to respond to certain unforeseen contingencies reveals that legal intervention may be important even when private contracting is possible. Specifically, the change from Unocal to "just say no" replaced the previous legal standard limiting the threat posed by takeover defenses with a regime that depends more on corporate contracting. This could have substantially reduced shareholder welfare if court oversight provided shareholders with important protections unavailable through private assignments. Thus, the fact that the corporate constituents can plausibly "contract" does not resolve the important issue of whether court oversight is significantly welfare enhancing.

Nor, for related reasons, do existing adaptive devices provide strong evidence concerning the optimal approach to takeover defenses. Were the existing legal regime an optimal legal regime, then the prevailing existing private arrangements could plausibly be presumptively optimal default provisions. Yet this conclusion does not necessarily hold if the existing legal regime is not optimal. This is particularly true where, as here, private contracting is distorted by unforeseen contingencies-such as the great variety of possible defensive measures available to the board. Unable to identify all such contingencies, shareholders may prefer to let boards employ defensive measures such as the poison pill or classified board because precluding such measures would result in boards using other, potentially more damaging measures without threat of legal sanction. Under a different legal regime, however, shareholders might well support very different arrangements.

Finally, and more generally, examination of the interaction of contracting problems and legal regimes reveals the importance of distinguishing between the different types of contracting costs, and carefully calibrating any legal intervention to respond to the particular type of contracting problem at issue. Whereas "contracting costs" may be reasonably addressed by mechanisms that replicate the agreements the par- 
ties would reach were contracting costless, concern with unforeseen contingencies requires lawmakers to consider mechanisms not available to the parties. Thus additional consideration should be given to both the precise nature of the contracting problems affecting the corporate parties and the differences between the mechanisms available to courts and private parties to redress such problems. 